\title{
Nutrient conditions in the subpolar North Atlantic during the last glacial period reconstructed from foraminifera-bound nitrogen isotopes
}

\author{
M. Straub, ${ }^{1}$ M. M. Tremblay, ${ }^{2}$ D. M. Sigman, ${ }^{3}$ A. S. Studer, ${ }^{1}$ H. Ren, ${ }^{4}$ \\ J. R. Toggweiler, ${ }^{5}$ and G. H. Haug $^{1}$ \\ Received 21 September 2012; revised 10 January 2013; accepted 15 January 2013; published 23 March 2013.
}

[1] Surface nitrate concentration is a potentially useful diagnostic in reconstructing the past circulation of high-latitude North Atlantic waters. Moreover, nutrient consumption in the North Atlantic surface impacts the atmospheric concentration of carbon dioxide. To reconstruct nutrient conditions in the subpolar North Atlantic region during the last ice age, a record of foraminifera-bound $\delta^{15} \mathrm{~N}$ was measured in Neogloboquadrina pachyderma (sin.) from core V28-73 south of Iceland $\left(57.2^{\circ} \mathrm{N}, 20.9^{\circ} \mathrm{W}\right)$. Foraminifera-bound $\delta^{15} \mathrm{~N}$ is up to $2 \%$ lower during the last ice age than during the Holocene, suggesting as much as $\sim 25 \%$ less complete nitrate consumption during the former. This is consistent with stronger light limitation associated with a deeper summer surface mixed layer, perhaps related to the formation of Glacial North Atlantic Intermediate Water previously suggested to have occurred near the core site. However, three single-point maxima in $\delta^{15} \mathrm{~N}$ in the glacial section and the sharp deglacial $\delta^{15} \mathrm{~N}$ rise coincide with Heinrich event layers. This suggests that increased water column stratification during Heinrich events, presumably due to surface freshening, reduced the nutrient supply from below and led to nearly complete nitrate consumption in the summertime mixed layer. The Heinrich layers in V28-73 are not accompanied by $\delta^{18} \mathrm{O}$ minima in either N. pachyderma (sin.) or Globigerinoides bulloides, which we tentatively attribute to extreme mixed-layer shoaling. The reconstructed subpolar North Atlantic upper water column changes — both glacial/interglacial and millennial - are inverse to those inferred for the Antarctic.

Citation: Straub, M., M. M. Tremblay, D. M. Sigman, A. S. Studer, H. Ren, J. R. Toggweiler, and G. H. Haug (2013), Nutrient conditions in the subpolar North Atlantic during the last glacial period reconstructed from foraminifera-bound nitrogen isotopes, Paleoceanography, 28, 79-90, doi:10.1002/palo.20013.

\section{Introduction}

[2] Today, the surface waters in most parts of the subpolar North Atlantic are relatively deplete in nitrate (and phosphate) by the end of the spring-to-summer biomass bloom. However, this region has undergone extensive changes since the last ice age. While glacial conditions were variable, the

\footnotetext{
Additional supporting information may be found in the online version of this article.

${ }^{1}$ Geological Institute, Department of Earth Sciences, ETH Zurich, Zurich, Switzerland.

${ }^{2}$ Department of Earth and Planetary Science, University of California at Berkeley, Berkeley, California, USA.

${ }^{3}$ Department of Geosciences, Princeton University, Princeton, New Jersey, USA.

${ }^{4}$ Lamont-Doherty Earth Observatory, Columbia University, Palisades, New York, USA.

${ }^{5}$ Geophysical Fluid Dynamics Laboratory, National Oceanic and Atmospheric Administration, Princeton, New Jersey, USA.

Corresponding author: Marietta Straub, Geological Institute, Department of Earth Sciences, ETH Zurich, Zurich, Switzerland. (marietta.straub@erdw. ethz.ch)

(C)2013. American Geophysical Union. All Rights Reserved. 0883-8305/13/10.1002/palo.20013
}

eastern subpolar North Atlantic region appears to have cooled as much as nearly any other ocean region yet studied [Waelbroeck, 2009], associated with a large southward migration of the Polar Front to a roughly zonal position at $45^{\circ} \mathrm{N}$, marked by a thick ice age deposit of ice-rafted detritus (IRD) [Ruddiman and McIntyre, 1977]. In addition, North Atlantic formation of subsurface water differed from the modern formation of North Atlantic Deep Water (NADW). Instead of NADW, a shallower form was produced (glacial North Atlantic Intermediate Water, or GNAIW). GNAIW may have been formed by wintertime convection in the open subpolar North Atlantic [Duplessy et al., 1991; Labeyrie et al., 1992; Oppo and Lehman, 1993] rather than in the Norwegian Sea where a large fraction of NADW currently forms.

[3] An increasing body of data points to the importance of feedbacks between the North Atlantic and the Southern Ocean in controlling high-latitude climate fluctuations and in driving the observed changes in atmospheric $\mathrm{CO}_{2}$ over glacial cycles [reviewed by Sigman et al., 2007, 2010]. When North Atlantic overturning decreased, it appears that Southern Ocean overturning increased [Broecker, 1998]. In the Southern Ocean, some of the strongest observations for this connection involve ocean biogeochemistry: during 
Heinrich events, when GNAIW formation was interrupted, Southern Ocean export production rose, suggesting increased nutrient supply from below [Anderson et al., 2009].

[4] However, the nature of biogeochemical change in the North Atlantic has been less clear. While bulk geochemical changes are ambiguous regarding export production changes in the North Atlantic [Manighetti and McCave, 1995], benthic foraminiferal data suggest lower productivity during the last ice age relative to the Holocene [Thomas et al., 1995] (Figure 1), as does the accumulation rate of biogenic calcium carbonate [Francois and Bacon, 1994]. The accumulation rates of planktonic and benthic foraminifera and of diatoms as well as species changes in benthic foraminifera suggest that Heinrich events were associated with even lower productivity (Figure 1, inset) [Broecker et al., 1992; Nave et al., 2007; Thomas et al., 1995]. If so, these changes might be attributed either to some form of light limitation or to changes in major nutrient supply from below. These alternatives have completely different implications for upper ocean conditions, the former suggesting a deeper mixed layer and the latter suggesting less exchange between the ocean surface and interior, likely yielding a shallower mixed layer.

[5] While the North Atlantic is the most studied region of the ocean, there is nevertheless much debate regarding how paleoceanographic measurements record conditions there. The $\delta^{18} \mathrm{O}$ of planktonic foraminifera-the most well developed of our paleoceanographic tools for this purposehas proven difficult to interpret in some North Atlantic records. Different down-core changes are observed for the two dominant species, Neogloboquadrina pachyderma (sinistral) and Globigerinoides bulloides (hereafter Nps and Gb) [Hillaire-Marcel and Bilodeau, 2000; Peck et al., 2006]. Moreover, for a given species, different glacial/ interglacial and millennial scale changes are observed in different regions of the subpolar North Atlantic. A number of competing explanations exist for these variations [Hillaire-Marcel and de Vernal, 2008; Rashid and Boyle, 2007; 2008]. As will be described below, the balance of the data appear to argue for strengthened vertical density stratification in the northwestern subpolar North Atlantic (and perhaps also the Norwegian Sea) during the last ice age, while there is some evidence for weakened stratification toward the east [de Vernal and Hillaire-Marcel, 2000; de Vernal et al., 2002; Duplessy et al., 1991], for example, off the western coast of the British Isles [Peck et al., 2006]. During Heinrich events, there is evidence for strengthening of stratification along the glacial IRD belt at $42-52^{\circ} \mathrm{N}$ (Figure 2a) and in the northwestern Atlantic [Bond et al., 1992; Bond and Lotti, 1995], while the conditions north of the IRD belt in the eastern North Atlantic are unclear [Cortijo et al., 1997]. A key goal in the cited studies is to reveal the roles of different regions in forming NADW or

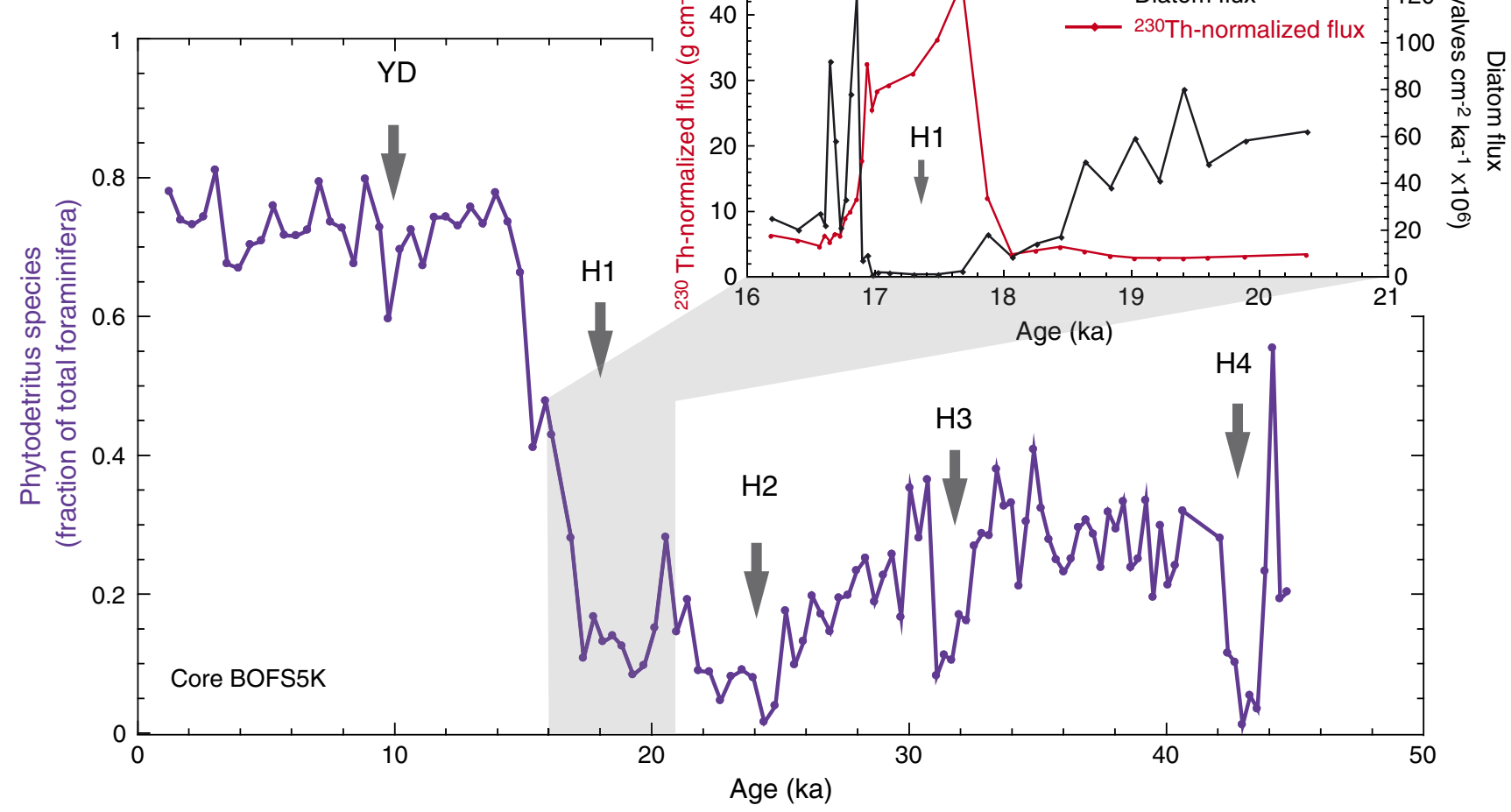

Figure 1. Records of subarctic North Atlantic productivity change since the last ice age. Main panel: abundance of benthic foraminifera species E. exigua and A. weddellensis, thought to respond strongly to high phytodetritus fluxes, relative to total benthic foraminifera in core BOSF5K [Thomas et al., 1995]. Inset: ${ }^{230}$ Th-normalized fluxes of total sediment and diatom frustules in core MD95-2027 [Nave et al., 2007] (see Figure 2 for locations). These data reflect the general consensus that subpolar North Atlantic export production was lower during the last ice age than during the Holocene and still lower during Heinrich events (labeled H1 through H4, following Thomas et al. [1995]). 

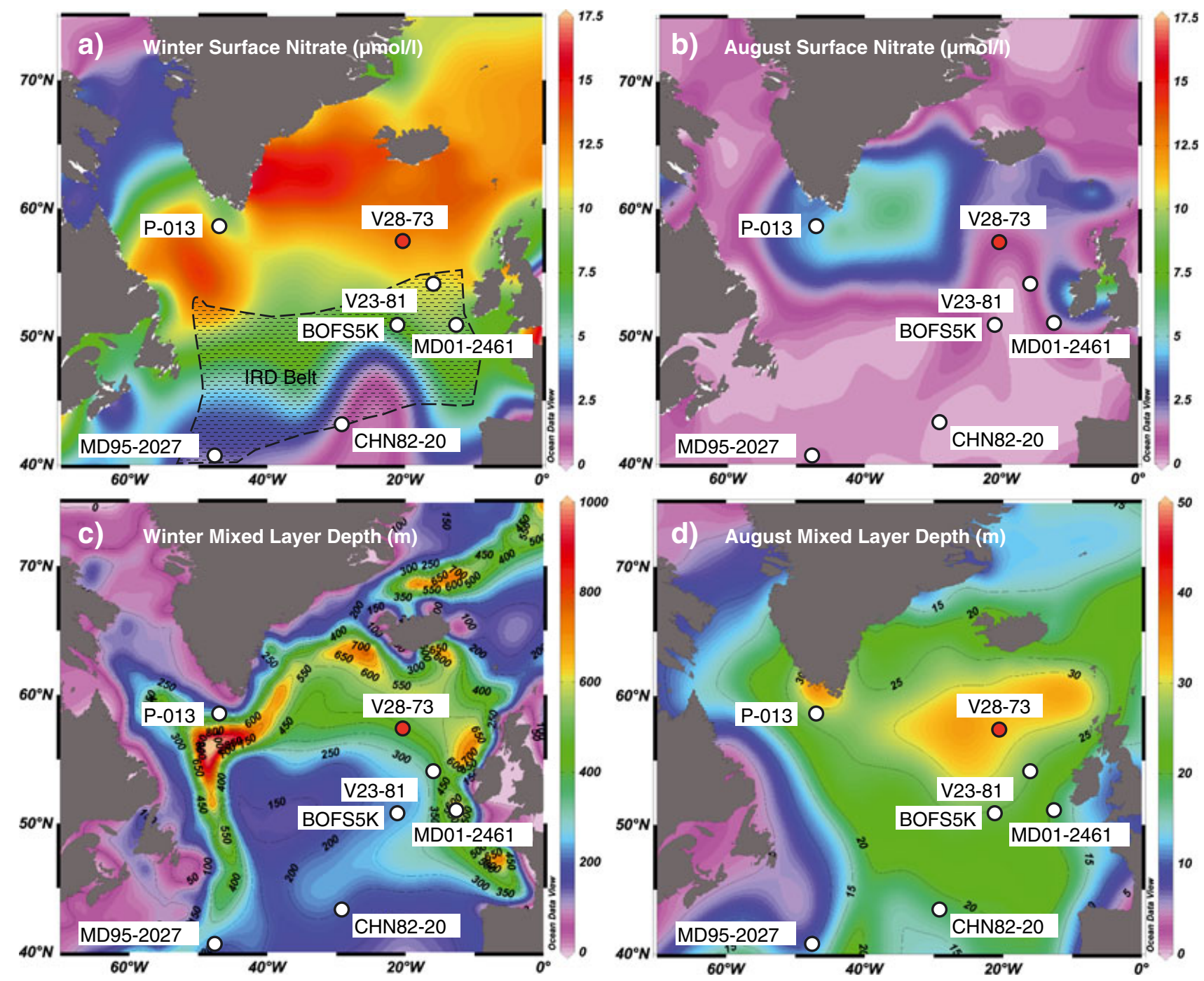

Figure 2. Surface nitrate concentration and mixed-layer depth in the subpolar North Atlantic during the late winter (a, c) and midsummer (b, d) and core locations. Core V28-73 (red circle) was used in this study. Core BOSF5K [Thomas et al., 1995] and core MD95-2027 [Nave et al., 2007] represent core locations of productivity proxies from Figure 1. P-013 [Hillaire-Marcel and Bilodeau, 2000] is representative of the western basin pattern of a larger $\mathrm{Nps}-\mathrm{Gb} \delta^{18} \mathrm{O}$ difference during the last ice age, suggesting a shallower mixed layer/stronger summer pycnocline in this region [see also de Vernal et al., 2002]. In contrast, MD01-2461 to the southeast is characterized by a decrease in the Nps-Gb $\delta^{18} \mathrm{O}$ difference and is interpreted as an ice age deepening of the mixed layer [Peck et al., 2006]. In core CHN82-20, $\delta^{18} \mathrm{O}$ of different planktonic foraminifera species was taken to indicate mixed-layer deepening during Heinrich events [Rashid and Boyle, 2007]. Core V23-81 shows $\mathrm{Nps} \delta^{18} \mathrm{O}$ minima associated with Heinrich events, a well-known pattern suggestive of stratification [Bond and Lotti, 1995] that is nevertheless not apparent in the $\delta{ }^{18} \mathrm{O}$ data from V28-73. Nitrate concentration data and mixed-layer depth estimates are from World Ocean Atlas [Monterey and Levitus, 1997; Garcia et al. 2010]. Note the change in depth scale from panel $\mathrm{c}$ to d. The location of the ice age "IRD belt" is indicated in panel a [Ruddiman and McIntyre, 1977].

GNAIW and to provide physical mechanisms for changes in the ventilation of the deep ocean by the North Atlantic.

[6] Biogeochemical conditions are a potentially important diagnostic in reconstructing past changes in high-latitude North Atlantic waters. For example, reconstruction of surface nutrients would distinguish whether the apparently reduced export production during the ice age and the Heinrich events during that period were due to stronger light limitation or reduced nutrient supply. This, in turn, would have implications for ocean circulation, in that nutrient supply occurs by vertical exchange of water between the surface layer and the ocean interior.

[7] Moreover, nutrient consumption in the North Atlantic surface impacts the atmospheric carbon dioxide concentration. Proposed mechanisms for lower atmospheric $\mathrm{CO}_{2}$ during past glacial periods include reduced overturning and/or reduced ocean/atmosphere gas exchange in the Southern Ocean, which would reduce the leakage of deeply sequestered $\mathrm{CO}_{2}$ back into the atmosphere from this region [Francois et al., 1997; Stephens and Keeling, 2000] 
(reviewed by Sigman et al. [2010]). These mechanisms rely on the assumption that the low nutrient concentration observed in the modern North Atlantic surface characterized the ice age North Atlantic as well [Marinov et al., 2008].

[8] Due to isotope fractionation during nitrate assimilation, the $\delta^{15} \mathrm{~N}$ of surface ocean nitrate covaries with the degree of nitrate consumption [Sigman et al., 1999], and the $\delta^{15} \mathrm{~N}$ of phytoplankton biomass and sinking matter generally tracks this variation [Altabet and Francois, 1994; Altabet et al., 1991], albeit with some specific exceptions for sinking $\mathrm{N}$ ([Altabet et al., 1991; Lourey et al., 2003] $\left(\delta^{15} \mathrm{~N}=\right.$ $\left.\left[\left({ }^{15} \mathrm{~N} /{ }^{14} \mathrm{~N}_{\text {sample }}\right) /\left({ }^{15} \mathrm{~N} /{ }^{14} \mathrm{~N}_{\text {reference }}\right)\right]-1\right)$, where the reference is atmospheric $\mathrm{N}_{2}$ ). The $\delta^{15} \mathrm{~N}$ of organic matter bound within the walls of planktonic foraminiferal tests covaries with the $\delta^{15} \mathrm{~N}$ of nitrate consumed in the euphotic zone across the global ocean, through grazing and predation of phyto- and zooplankton in the upper ocean [Ren et al., 2009, 2012a]. "Foraminifera-bound" $\delta^{15} \mathrm{~N}$ (hereafter FB- $\delta^{15} \mathrm{~N}$ ) measurements have just begun in core top sediments from high-latitude regions. The demonstrated $\delta^{15} \mathrm{~N}$ connections between nitrate consumption and surface particles in these regions and between surface particles and $\mathrm{FB}-\delta^{15} \mathrm{~N}$ in the low-latitude and midlatitude ocean, taken together, argue that down-core records of $\mathrm{FB}-\delta^{15} \mathrm{~N}$ should capture surface nutrient changes in the high-latitude oceans. The results to date support this covariation of $\mathrm{FB}-\delta^{15} \mathrm{~N}$ with nitrate consumption, so far most convincingly for $\mathrm{Nps}$ (H. Ren, unpublished results). While bulk sedimentary $\delta^{15} \mathrm{~N}$ has been used in the same context [Altabet and Francois, 1994], this approach is of questionable robustness in environments where the preservation of sedimentary organic matter is low [Altabet, 2006] and/or terrigenous inputs are high [Schubert and Calvert, 2001]. Indeed, bulk sedimentary $\mathrm{N}$ fails to capture signals recorded by $\mathrm{FB}-\delta^{15} \mathrm{~N}$ in low-latitude North Atlantic and South China Sea records [Meckler et al., 2011; Ren et al., 2009, 2012b]. The Heinrich layers in high-latitude North Atlantic sediments are known to be contaminated with terrigenous N [Huon et al., 2002], and terrestrial organic matter is generally more abundant in the North Atlantic sediments during the last ice age than during the Holocene [Villanueva et al., 1997]. While diatom frustule-bound $\mathrm{N}$ represents an alternative to foraminifera-bound $\mathrm{N}$ as a protected, upper ocean-derived form of $\mathrm{N}$ in deep sea sediments, the low biogenic opal content in the subarctic North Atlantic sediments makes it a less promising analytical target in this region.

[9] In an effort to provide new constraints on surface nutrient consumption in the subpolar North Atlantic during the last ice age, we have measured a down-core record of FB- $\delta^{15} \mathrm{~N}$. The record is the first of its kind from a polar/subpolar environment, and it shows changes that are of fundamental significance to our understanding of the subpolar North Atlantic during the last ice age.

\section{Materials and Methods}

[10] Core V28-73 was raised in 1970 from $57.18^{\circ} \mathrm{N}$ $20.87^{\circ} \mathrm{W}$ and $2063 \mathrm{~m}$ depth, and it is curated at the Lamont-Doherty Deep-Sea Sample Repository (Figure 2, red circle). Twenty-two samples were collected for foraminifera picking. The upper $1 \mathrm{~m}$ was sampled roughly every $10 \mathrm{~cm}$ and then at less regular intervals down to $3.45 \mathrm{~m}$, according to the condition of core working half. The core has previously yielded few significant paleoceanographic results, its sedimentation rate is modest, and its use required us to generate a number of basic ancillary measurements (see below). These shortcomings beg the question of why this core was used, given the relative abundance of higher resolution, well-studied North Atlantic sediment cores. A number of issues were at work. First, V28-73 is in the subarctic North Atlantic region that has significant wintertime mixing today (Figure $2 \mathrm{a}$ and $\mathrm{c}$ ), increasing the potential for major changes in surface nutrient concentration in the past relative to, for example, sites in the ice age IRD belt [Figure 2a, Ruddiman and McIntyre, 1977]. Second, V28-73 is in the region suspected to be involved in GNAIW formation [Oppo and Lehman, 1993]. Third, we sought to avoid the region of high summertime surface nitrate off the southern tip of Greenland (Figure 2c), the origin and significance of which is not clear. Future work will focus on higherquality sediment cores with higher accumulation rates. Nevertheless, it should be noted that $\mathrm{FB}-\delta^{15} \mathrm{~N}$ analysis is well suited to cores that are no longer useful for sedimentary geochemical studies, as foraminifera-bound $\mathrm{N}$ is unaffected by storage.

\subsection{Foraminifera-Bound N Isotope Analysis}

[11] The sediment samples were sieved for the size fraction $>63 \mu \mathrm{m}$. From this coarse fraction, planktonic foraminifera species Nps were picked under a binocular microscope. Nps was the most abundant species, with Gb uniformly present but not as abundant. Three to seven milligrams of foraminifera (i.e., 800-1000 specimens) per sample were used to carry out the analyses.

[12] Samples were cleaned and analyzed for $\mathrm{FB}-\delta^{15} \mathrm{~N}$ and $\mathrm{N}$ content following the protocol of Ren et al. [2009]. The cleaned samples were dried overnight at $60^{\circ} \mathrm{C}$. Three to seven milligrams of cleaned sample were weighed into a previously combusted vial and dissolved in $4 \mathrm{~N} \mathrm{HCl}$ (40-60 $\mu \mathrm{L}$ per sample). Basic potassium persulfate oxidizing solution (see below) was then added to each vial and to vials containing organic standards and procedural blanks. The persulfate oxiziding solution for organic $\mathrm{N}$ conversion to nitrate was made up at the time of processing; $1 \mathrm{~g}$ ACS-grade sodium hydroxide and $1 \mathrm{~g}$ potassium persulfate were dissolved in $100 \mathrm{~mL}$ deionized water (DW). For the samples measured here, we used $1 \mathrm{~mL}$ of persulfate reagent for the blanks, oxidation standards, and foraminifera samples. The vials were autoclaved for 1 hour ( 1.5 hours including warmup and cool-down time) on a slow vent setting. For nearly all samples, replicates were partitioned after the cleaning step. Two replicates of each sample were oxidized and analyzed several weeks apart.

[13] With each set of replicates, oxidation standards of known nitrogen concentration and isotopic composition were run to correct for the nitrogen blank of the persulfate reagent and sample processing. The organic standards used here were USGS 40 and USGS 41, as well as two in-house standards composed of a solution mixture of 6-aminocaproic acid and glycine, with a $\delta^{15} \mathrm{~N}$ of $3.4 \%$ and $5.4 \%$ (determined by analysis of the concentrated standard solutions with EA-IRMS). The standard sizes were chosen to match to the expected $\mathrm{N}$ content of the foraminifera samples. A minimum of 10 organic standards and three to five blanks were analyzed per batch of samples, allowing for a 
correction for the persulfate blank. The Nps samples had $\mathrm{N}$ contents of $3-5 \mu \mathrm{molN}$ per gram sample, typically yielding nitrate concentrations in the oxidation solutions of $10-20 \mu \mathrm{M}$, whereas the blank ranged between 0.3 and $0.7 \mu \mathrm{M}$. Average $\delta^{15} \mathrm{~N}$ for each sample depth is shown; error bars indicate the estimated standard deviation from oxidation replicates (Figure 3 ).

[14] Bulk sediment $\delta^{15} \mathrm{~N}$ was measured every $\sim 10 \mathrm{~cm}$. The total $\mathrm{N}$ content of the sediment was liberated and analyzed as $\mathrm{N}_{2}$ using a Thermo Fisher elemental analyzer Series 1112 coupled to a Thermo Delta V Plus mass spectrometer (Thermo Fisher Scientific, Waltham MA) at ETH Zurich. Between 40 and $60 \mathrm{mg}$ sediment was analyzed. Standards of atropine and peptone were measured in the same run. Standard deviations for both standards were $<0.2 \%$. These data are compared with the FB- $\delta^{15} \mathrm{~N}$ results in Auxillary Figure A1.

\subsection{Foraminiferal and Bulk Sediment Carbonate Oxygen Isotope Analysis}

[15] Oxygen isotopes of the planktonic foraminifera species Nps and Gb were measured at ETH Zurich. Between 30 to 40 individual foraminifera species were cleaned using the following approach: $1000 \mu \mathrm{L}$ DW was added to each sample which then was ultrasonicated for 3-5s. After

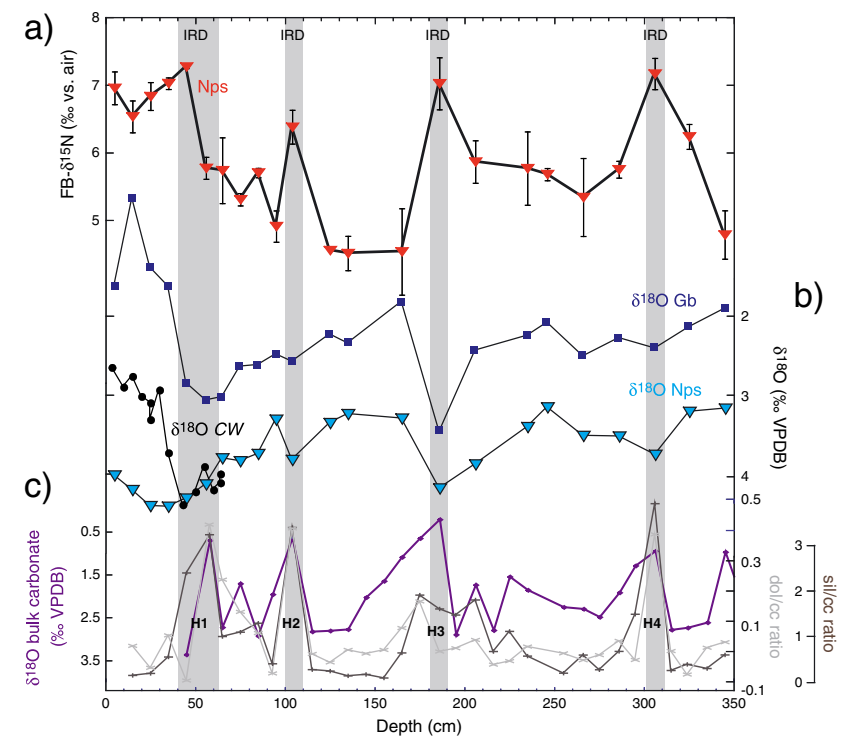

Figure 3. Down-core data from this study. (a) $\mathrm{FB}-\delta^{15} \mathrm{~N}$ of $N$. pachyderma s.; (b) calcite $\delta^{18} \mathrm{O}$ of $G$. bulloides, $N$. pachyderma s., and C. wuellerstorfi and (c) ratios of detrital dolomite (dol) and silicate (sil) to calcite (cc) based on FTIR spectra as well as bulk carbonate $\delta^{18} \mathrm{O}$, an additional measure of the dolomite-to-calcite ratio. Gray bars identify the IRD rich intervals, based on visual analysis of the sieved coarse fractions (>63 $\mu \mathrm{m})$. Heinrich event layers typically include detrital carbonate with some dolomite, so the dol/cc and bulk carbonate $\delta^{18} \mathrm{O}$ minima indicate that an IRD layer is associated with a Heinrich event, although dolomite does not typically pervade each Heinrich IRD layer, often occurring toward the top [Bond et al., 1992] (as in $\mathrm{H} 3$ here). Peaks in $\mathrm{FB}-\delta^{15} \mathrm{~N}$ and weak maxima in the $\delta^{18} \mathrm{O}$ of both planktonic foraminifera species coincide with the Heinrich event IRD layers. The $\delta^{18} \mathrm{O}$ data of C. wuellerstorfi are from Oppo and Lehman [1993]. removing the liquid using a syringe, $200 \mu \mathrm{L}$ methanol was added and the sample ultrasonicated again for $3-5 \mathrm{~s}$; the liquid was then removed. The sample was rinsed with DW two to three times and dried in an oven at $60^{\circ} \mathrm{C}$ overnight.

[16] $\delta^{18} \mathrm{O}$ and $\delta^{13} \mathrm{C}$ for foraminifera and bulk sediment analysis were performed with a Thermo GasBench II coupled to a Thermo Delta V Plus mass spectrometer, following the protocol of Breitenbach and Bernasconi [2011]. The cleaned foraminifera samples were crushed and 35-80 $\mu \mathrm{g}$ weighed into $4.5 \mathrm{~mL}$ vials; for the bulk sediment, $80-130 \mu \mathrm{g}$ were weighed in. The average of the standard deviation of single $\delta^{18} \mathrm{O}$ measurements of $\mathrm{Np}$ and $\mathrm{Gb}$ is $\sim 0.04 \%$. Benthic foraminiferal $\delta^{18} \mathrm{O}$ was measured previously on the species Cibicidoides wuellerstorfi down to $64 \mathrm{~cm}$ by Oppo and Lehman [1993].

\subsection{Fourier Transform Infrared Spectrophotometry}

[17] Fourier transform infrared (FTIR) spectrophotometry was used as a rapid approach for measuring down-core changes in detrital silicates and dolomite, to identify maxima in ice rafted detritus and Heinrich layers in particular [Ji et al., 2009]. The analyses were conducted in the lab of Prof. Satish Myneni at Princeton University, using a Bruker IFS 66 v/s FTIR spectrometer, in attenuated total reflectance (ATR) mode. Roughly $1 \mathrm{cc}$ of sample was homogenized using a mortar and pestle, and $1 \mathrm{~mm}^{2}$ of the powder was applied to the ATR crystal. Air was used as the background spectra. Samples were held against a single reflection diamond crystal ATR accessory. The signal was collected by a liquid nitrogen cooled mercury cadmiumtelluride detector. Peak fitting was performed by GRAMS/AI (Thermo Electron software, Thermo Fisher Scientific, Waltham MA). The spectra from each sample were interpreted for ratios of dolomite/calcite and silicate/dolomite to identify samples with high IRD and high dolomite fractions.

\section{Results}

\subsection{Foraminiferal Oxygen Isotopes and Ice Rafted Detritus}

[18] Based on the $\delta^{18} \mathrm{O}$ of $\mathrm{Gb}$ and the benthic species $C$. wuellerstorf [Oppo and Lehman, 1993], we identify the last ice age at $45 \mathrm{~cm}$ and deeper (Figure 3). Remarkably, the $\delta^{18} \mathrm{O}$ of Nps shows no decrease into the Holocene, suggesting that other effects on $\mathrm{Nps} \delta^{18} \mathrm{O}$ offset the effect of the deglacial decline in global ocean $\delta^{18} \mathrm{O}$ (see discussion below).

[19] Of the sampled sediments, four IRD peaks were recognized qualitatively from the sieved coarse fractions (vertical gray bars in Figure 3). At or near each visually identified IRD maximum, the FTIR data indicate a peak in silicate-to-carbonate ratio. Moreover, these depths also correspond to FTIR-identified peaks in dolomite-to-calcite ratio and local minima in bulk carbonate $\delta^{18} \mathrm{O}$, as expected for Heinrich layers [Hodell and Curtis, 2008; Ji et al., 2009]. Thus, we hereafter attribute these IRD-rich layers to Heinrich events (see $\mathrm{H} 1$ to $\mathrm{H} 4$ identifications in Figure 3). In the region of V28-73 (Figure 2), the appearance of Heinrich layers with detrital carbonate is not universal, and the layers are much less robust than to the south and the west [Bond et al., 1992]. This explains the very weak nature of the Heinrich-related dolomite-to-calcite maxima and bulk carbonate $\delta^{18} \mathrm{O}$ minima in this core relative to cores from further south [Hodell and Curtis, 2008]. It also emphasizes 
the potential power of $\mathrm{FB}-\delta^{15} \mathrm{~N}$ to study these events: despite the weak sedimentological signature of the Heinrich events at this site, $\mathrm{FB}-\delta^{15} \mathrm{~N}$ clearly responds to them (see below).

[20] Each of the IRD-rich layers coincides with a weak $\left(<0.5 \%\right.$ ) local maximum in the $\delta^{18} \mathrm{O}$ of both $\mathrm{Gb}$ and Nps. Heinrich events as sampled in the glacial IRD belt at $42-52^{\circ} \mathrm{N}$ [Grousset et al., 1993; Ruddiman and McIntyre, 1977] and in the western North Atlantic are typically characterized by $\mathrm{Nps} \delta^{18} \mathrm{O}$ minima [Bond et al., 1992; Bond and Lotti, 1995], the opposite sense of $\delta^{18} \mathrm{O}$ change that we observe associated with our IRD peaks (Figure 2, core V23-81). However, various behaviors in $\mathrm{Nps} \delta{ }^{18} \mathrm{O}$ have been observed in the eastern subpolar North Atlantic [Peck et al., 2006]. In this region, Cortijo et al. [1997] identified a meridional gradient in the $\mathrm{Nps} \delta^{18} \mathrm{O}$ response to Heinrich event 4 , with a Nps $\delta^{18} \mathrm{O}$ decrease occurring in the IRD belt but a slight $\delta^{18} \mathrm{O}$ increase in region of V28-73 to the North of the IRD belt, with which our data are consistent.

\subsection{Foraminifera-Bound Nitrogen Isotopes}

[21] Foraminifera-bound $\delta^{15} \mathrm{~N}$ is generally lower during the last glacial period ( $>45 \mathrm{~cm}$ depth) than during the Holocene $(\leq 45 \mathrm{~cm}$ depth) (Figure $3 \mathrm{a})$. The lowest $\delta^{15} \mathrm{~N}$ is observed between 125 and $175 \mathrm{~cm}$, with $\delta^{15} \mathrm{~N}$ apparently slightly higher in the interval from 200 to $300 \mathrm{~cm}$.

[22] Against this background of lower $\mathrm{FB}-\delta^{15} \mathrm{~N}$ during the last ice age, three single-point maxima in FB- $\delta^{15} \mathrm{~N}$ are observed within the glacial section at 104, 186, and $306 \mathrm{~cm}$, reaching similar to interglacial values. These depths coincide with the Heinrich layers as identified above. The apparent $\mathrm{H} 1$ IRD layer is also associated with a sharp $\mathrm{FB}-\delta^{15} \mathrm{~N}$ increase, although not in its deeper half (which is rich in volcanic grains as well), and $\mathrm{FB}-\delta^{15} \mathrm{~N}$ then remains high through the deglaciation and Holocene.

[23] Tentatively assigning Heinrich events to the observed IRD maxima, the IRD maximum at $45 \mathrm{~cm}$ is taken as $\mathrm{H} 1$ $(\sim 17 \mathrm{ka})$ (given its occurrence at the end of glacial interval), $110 \mathrm{~cm}$ is taken as H2 ( 24 ka), $185 \mathrm{~cm}$ as H3 $(\sim 31 \mathrm{ka})$, and $310 \mathrm{~cm}$ as $\mathrm{H} 4(\sim 38 \mathrm{ka})$ [Hemming, 2004]. With these assignments (or also if one Heinrich event has been missed), the $\mathrm{FB}-\delta^{15} \mathrm{~N}$ decrease from 200 to $300 \mathrm{~cm}$ to the minimum between 125 and $175 \mathrm{~cm}$ coincides with the global climate cooling from marine isotope stage (MIS) 3 to MIS 2 (the Last Glacial Maximum, LGM). On the orbital time scale, this suggests a consistent correlation between climate and FB- $\delta^{15} \mathrm{~N}$ (and thus nitrate consumption) at V28-73. That is, just as MIS 3 is an intermediate climate state, so too is its $\delta^{15} \mathrm{~N}$ intermediate between MIS 1 (Holocene) and MIS 2 (LGM) values.

[24] Bulk sediment $\delta^{15} \mathrm{~N}$ appears to capture partially the higher $\delta^{15} \mathrm{~N}$ of Heinrich events, albeit as a weaker signal (Auxillary Figure A1). However, there is no agreement with regard to the LGM/Holocene $\delta^{15} \mathrm{~N}$ difference, with bulk sediment $\delta^{15} \mathrm{~N}$ arguing for no clear change but a mid-Holocene decrease. Given the work documenting the importance of terrestrial organic matter in glacial North Atlantic sediments [Villanueva et al., 1997], especially during Heinrich events [Huon et al., 2002], we interpret the disagreements as deriving from the effect of allochthonous $\mathrm{N}$ on bulk sediment $\delta^{15} \mathrm{~N}$, and the bulk sediment $\delta^{15} \mathrm{~N}$ data are not discussed further.

\section{Interpretation and Discussion}

\subsection{The Last Ice Age}

[25] Today, productivity and nutrient conditions in the subpolar eastern North Atlantic are highly seasonal, dominated by the "North Atlantic Bloom," which typically begins in April to May [Siegel et al., 2002]. In subpolar and polar regions, the high-latitude North Atlantic included, the $\delta^{15} \mathrm{~N}$ of suspended and sinking particulate $\mathrm{N}(\mathrm{PN})$ is initially low as the seasonal bloom begins, due to preferential consumption of ${ }^{14} \mathrm{~N}$-nitrate [Altabet et al., 1991]. As the residual nitrate pool increases in $\delta^{15} \mathrm{~N}$, so does the PN generated from it. In this and other polar regions, the spring-to-summer integrated, flux-weighted $\delta^{15} \mathrm{~N}$ of the sinking PN is similar to that of the nitrate that has been extracted from surface waters during this period [Altabet and Francois, 2001; Altabet et al., 1991; Lourey et al., 2003]. For our site, where summertime nitrate consumption is nearly complete today (Figure 2, see below), the sinking $\delta^{15} \mathrm{~N}$ should converge on the $\delta^{15} \mathrm{~N}$ of the wintertime nitrate supply.

[26] The $\mathrm{N}$ isotope dynamics associated with nitrate consumption are propagated to foraminifera by their feeding on phytoplankton, zooplankton, and/or detritus deriving from euphotic zone production. The measurements to date of net tow, sediment trap, and surface sediment foraminifera suggest that the FB- $\delta^{15} \mathrm{~N}$ of low latitude, spinose, symbiont bearing, euphotic zone dwelling species (G. ruber, G. sacculifer, $O$. universa) is similar to the $\delta^{15} \mathrm{~N}$ of nitrate consumed in the surface layer. In contrast, nonspinose, nonsymbiotic forms (the category into which $\mathrm{Nps}$ falls) tend to have a $\delta^{15} \mathrm{~N} \sim 2-3 \%$ o higher than the nitrate supply to the surface [Ren et al., 2012a]. Consistent with this expectation, Nps FB- $\delta^{15} \mathrm{~N}$ is found to be similar to the $\delta^{15} \mathrm{~N}$ of diatom frustule-bound organic $\mathrm{N}$ in the subarctic North Pacific, both of which appear to be elevated by $\sim 2 \%$ relative to the expected sinking flux ( $\mathrm{H}$. Ren, in preparation). The tendency for $\mathrm{FB}-\delta^{15} \mathrm{~N}$ to be similar to that of the nitrate supply likely derives from the feeding of foraminifera on zooplankton and large phytoplankton, the $\delta^{15} \mathrm{~N}$ of which is higher than bulk suspended PN but similar to the nitrate supply [Ren et al., 2012a]. The $\delta^{15} \mathrm{~N}$ elevation of nonspinose forms (relative to spinose forms) may arise from their consumption of some deeper suspended particles and/or their lack of symbionts, the latter leading to full expression of the trophic ${ }^{15} \mathrm{~N}$ enrichment [Ren et al., 2012a; Uhle et al., 1997].

[27] Globally, and especially in subpolar waters, the seasonal variation in planktonic foraminiferal production and flux is highly correlated with surface ocean productivity [Eguchi et al., 2003; Thunell and Reynolds, 1984; Thunell and Honjo, 1987]. Temperature obviously plays a major role in global species patterns, and it also contributes to seasonal changes in species assemblage, especially in mid-latitude to low-latitude regions [Zaric et al., 2005]. However, in polar and subpolar regions, species diversity is low, and the dominant dynamic is of Nps producing the greatest quantity of shells during the spring-to-summer bloom [Sautter and Thunell, 1989]. Since the foraminifera production peak roughly coincides with this bloom and the associated increase in sinking material, it is reasonable to expect that FB- $\delta{ }^{15} \mathrm{~N}$ will track the seasonal nitrate drawdown in roughly the same way as it is recorded in the $\delta^{15} \mathrm{~N}$ of surface nitrate, suspended PN, and sinking N. In this context, the observations 
from lower-latitude sites of a strong correlation between FB- $\delta^{15} \mathrm{~N}$ and the $\delta^{15} \mathrm{~N}$ of nitrate supply to the euphotic zone [Ren et al., 2012a] represent the end-member case of complete nitrate consumption. In some data from the subarctic North Atlantic, there is the suggestion of a midsummer decrease in Nps flux, leading to the identification of a secondary flux peak in the late summer [Jonkers et al., 2010]. While the $\mathrm{N}$ isotope dynamics associated with this secondary peak requires further study, a similar link between nitrate consumption and the $\mathrm{N}$ isotopes should apply.

[28] Over the course of the North Atlantic spring bloom, nitrate concentration is drawn down from $>10 \mu \mathrm{M}(\sim 15 \mu \mathrm{M}$ at the site of V28-73) to levels of typically $1 \mu \mathrm{M}$ or lower by July/August (Figure 2a and b). Based on these values, by the end of the spring/summer bloom, nitrate consumption is $\geq 90 \%$ at our site, such that the $\delta^{15} \mathrm{~N}$ of the organic $\mathrm{N}$ produced over the course of the spring and summer should be within $\sim 1 \%$ of the wintertime nitrate supply. It is thus expected that the relationship between the nitrate supply and $\mathrm{FB}-\delta^{15} \mathrm{~N}$ at this site in the North Atlantic would approximate the relationship observed in lower-latitude sites characterized by complete nitrate consumption. Indeed, the $\mathrm{FB}-\delta^{15} \mathrm{~N}$ of Holocene Nps, 6.6-7.0\% (Figure 3), is $\sim 2 \%$ o higher than the $\delta^{15} \mathrm{~N}$ of 4.5-5.0\% in NADW [Sigman et al., 2000; Sigman et al., 2009] and shallow subsurface nitrate measured in the high-latitude North Atlantic (D.M. Sigman, unpublished results). This $\mathrm{FB}-\delta^{15} \mathrm{~N}$ is consistent with expectations, given the previous observation from lower-latitude sites of a $\sim 2-3 \%$ elevation of $\mathrm{FB}-\delta^{15} \mathrm{~N}$ in nonsymbiotic foraminifera relative to the nitrate consumed in the euphotic zone.

[29] The generally lower FB- $\delta^{15} \mathrm{~N}$ of the last glacial period relative to the Holocene suggests that the $\delta^{15} \mathrm{~N}$ of organic $\mathrm{N}$ produced in the euphotic zone (and fed upon by Nps) was lower during the last ice age. If anything, tropical North
Atlantic $\mathrm{FB}-\delta^{15} \mathrm{~N}$ records might allow for higher-not lower $-\delta^{15} \mathrm{~N}$ for deep and intermediate-depth nitrate in the North Atlantic during the last ice age, and $\mathrm{N}$ fixation changes in the North Atlantic are also of the opposite sign required to explain the glacial/interglacial $\delta^{15} \mathrm{~N}$ change at V28-73 via changes in thermocline nitrate $\delta^{15} \mathrm{~N}$ [Meckler et al., 2011; Ren et al., 2009].

[30] In general, it might seem possible for a given foraminifera species to shift its season of maximum growth, leading the shells to record the $\mathrm{N}$ isotopic composition of a different time of year and thus introduce a bias into the reconstruction of surface nitrate consumption. However, as described above, foraminifera production, especially for $\mathrm{Nps}$, is observed to be tightly tied to the spring to summer bloom in polar and subpolar waters. Furthermore, if the timing of Nps production in the subpolar North Atlantic was different during the last ice age than during the Holocene, it would have involved a shift to closer to peak summer [Fraile et al., 2009]. For a constant timing of the spring to summer bloom, this would tend to bias FB- $\delta^{15} \mathrm{~N}$ to be higher during the LGM than during the Holocene, in the opposite sense of the observations.

[31] Thus, short of unknown dynamics, the sole explanation for the lower $\mathrm{FB}-\delta^{15} \mathrm{~N}$ during the last ice age is that summertime nitrate consumption was less complete (summertime surface nitrate concentration was higher), leading to a lower $\delta^{15} \mathrm{~N}$ for the nitrate assimilated into upper ocean organic $\mathrm{N}$ and thus a lower $\delta^{15} \mathrm{~N}$ in the surface PN pools (Figure 4). The amplitude of FB- $\delta^{15} \mathrm{~N}$ change provides some guidance as to the quantitative changes in surface nitrate, although with uncertainties exacerbated by the lack of specific ground-truthing data from the North Atlantic. If the isotope effect for nitrate assimilation is taken to be $8 \%$ in this region [Altabet et al., 1991], the $\sim 2 \%$ decrease in $\mathrm{FB}-\delta^{15} \mathrm{~N}$ would a) Holocene

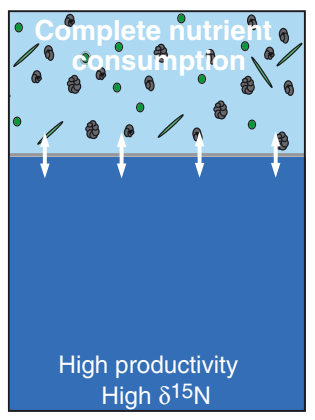

b) Ice Age

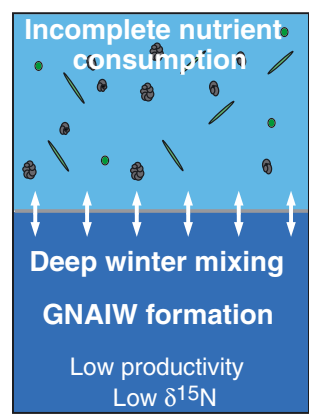

c) Heinrich Events

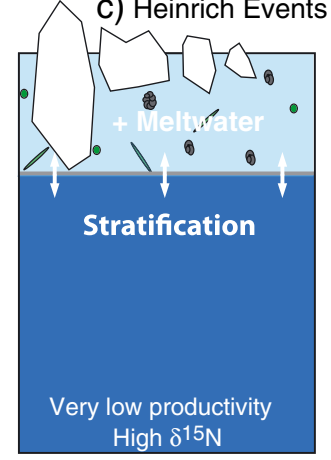

d) Density

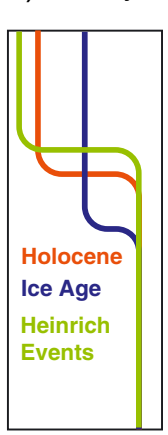

e) Nitrate $(\mu \mathrm{M})$

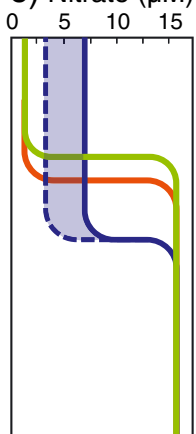

Figure 4. Interpretation of conditions at the North Atlantic site of V28-73 during the Holocene (a), LGM (b), and Heinrich events (c), with schematic depth profiles of proposed changes in mixed-layer depth, surface density, and nitrate concentration $(\mathrm{d}, \mathrm{e})$. The Holocene (a) is characterized by wintertime nitrate supply followed by a shallow summer mixed layer, leading to high productivity and nearly complete nitrate consumption. The LGM (b) is interpreted as having a deeper summertime mixed layer, with light limitation leading to lower productivity and less complete nitrate consumption (lower $\delta^{15} \mathrm{~N}$ ). The deeper mixed layer of the LGM may have been related to GNAIW formation in this region. The two alternatives for LGM surface nitrate concentration relate to different choices for the isotope effect of nitrate assimilation ( $8 \%$ o for dashed line, $5 \%$ o for the solid line; see text). During Heinrich events (c), an apparent further decline in productivity from background glacial conditions coupled with more complete nitrate consumption (higher $\delta^{15} \mathrm{~N}$ ) suggest a strong reduction in nitrate supply. This is consistent with previous suggestions of stronger stratification due to iceberg-associated meltwater and an extreme shoaling of the mixed layer. One uncertainty in panel e is the nitrate concentration of the deep waters through time. 
yield LGM nitrate consumption $20 \%$ less than in the Holocene. If the isotope effect were instead assumed to be 5\%, a rough lower bound for field estimates [DiFiore et al., 2010], the FB- $\delta^{15} \mathrm{~N}$ decrease would translate to $35 \%$ less consumption during the LGM. In either case, the reconstructed decrease in the degree of nitrate consumption is modest. If the minimum summertime nitrate concentration at our site is taken to be $\sim 1 \mu \mathrm{M}$ during the Holocene, assuming a constant wintertime nitrate concentration of $15 \mu \mathrm{M}$, the summertime concentration would have been $<7 \mu \mathrm{M}$ during the LGM (Figure 4). This is similar to what can be found in midsummer today at the regional nitrate concentration maximum $\sim 15^{\circ}$ west of V28-73 (Figure $2 \mathrm{~b}$ ). Thus, the changes suggested by the FB- $\delta{ }^{15} \mathrm{~N}$ data do not appear to require LGM nutrient conditions radically different from those of the modern North Atlantic. Furthermore, even if the reconstructed nutrient concentration change applied directly to the preformed nutrient content of NADW/GNAIW, the change would not be adequately large to substantially alter the role of the North Atlantic as a region where water with low preformed nutrients enters the ocean interior because the Antarctic end-member has a much higher preformed nitrate concentration, $>32 \mu \mathrm{M}$ [Toggweiler et al., 2003].

[32] Nevertheless, we are left with the important mechanistic question of why nitrate consumption would be less complete during the last ice age. As described above, the preponderance of data argues for reduced ice age productivity in this region (Figure 1) [Francois and Bacon, 1994; Manighetti and McCave, 1995; Thomas et al., 1995; van Weering and de Rijk, 1991], and this has been associated with the classic observation of a shift in the polar front from a position well to the north of our site today to an ice age position well south of V28-73 [McIntyre et al., 1976]. The existing temperature reconstructions do not suggest that spring and summer sea ice cover would have been adequate to reduce ice age productivity near our site [de Vernal and Hillaire-Marcel, 2000; Sarnthein et al., 2003]. Neither does stronger iron limitation seem plausible for the ice age North Atlantic conditions [Fuhrer et al., 1999]. Thus, the coupled decreases in productivity and nutrient consumption would seem to call for a hydrographically driven reduction in light availability, that is, a deeper spring-to-summer wind-mixed layer [Siegel et al., 2002] (Figure 4).

[33] It is unclear whether our interpretation of a deeper LGM summer mixed layer fits with other observations from the region. A changing $\delta^{18} \mathrm{O}$ difference between $\mathrm{Gb}$ and Nps in the North Atlantic has been interpreted as an index of upper ocean stratification over glacial cycles, based on evidence that Nps records submixed layer conditions in the modern North Atlantic while Gb at least partially records summer mixed layer conditions [de Vernal et al., 2002; Jonkers et al., 2010; Peck et al., 2006]. As in our study, in a nearby core to the southeast, Peck et al. [2006] observe a reduced Gb-Nps $\delta^{18} \mathrm{O}$ difference during the last ice age, which they interpret as indicating weaker upper ocean stratification (Figure 2, core MD01-2461). We argue that this change might be better described in terms of mixed-layer depth. While $\mathrm{Gb}$ shows the expected $\delta^{18} \mathrm{O}$ rise during the ice age (due to whole ocean $\delta^{18} \mathrm{O}$ change), Nps does not. This implies that $\mathrm{Nps} \delta^{18} \mathrm{O}$ is declining relative to regional waters. This is consistent with a mixed-layer deepening that would have moved the base of mixed layer below the common depth of Nps during the LGM, such that both $\mathrm{Gb}$ and Nps recorded mixed-layer $\delta^{18} \mathrm{O}$. As a deeper mixed layer is typically associated with weaker upper ocean stratification in polar regions, this view is consistent with that of Peck et al. [2006].

[34] In contrast, in the northwestern North Atlantic south of the Labrador Sea, Hillaire-Marcel and Bilodeau [2000] observe a greater difference $\delta^{18} \mathrm{O}$ difference between $\mathrm{Gb}$ and Nps during the last ice age (Figure 2, core P-013). The same logic as Peck et al. [2006] leads Hillaire-Marcel and Bilodeau [2000] to propose generally stronger stratification in that region during the last ice age. While these findings would seem contradictory, de Vernal et al. [2002] deduce from dinoflagellate cyst species a stronger spatial variation in upper ocean stratification during the last ice age, with a strengthening of the halocline in the western subpolar North Atlantic but a weakening of the halocline toward the east. The FB- $\delta^{15} \mathrm{~N}$ data would seem to agree with the interpretation of a deeper mixed layer in the eastern than western North Atlantic, suggesting in addition that the LGM summer mixed layer in the east was deeper than during the Holocene.

[35] Physical arguments can be made either way as to whether summer mixed layer should have been deeper in the LGM subpolar North Atlantic. A southward migration of the winds may have left the subpolar North Atlantic far north of the path of the westerly winds. Such a shift would have tended to reduce local wind-driven upwelling. It might have also exported less freshwater from the region due to Ekman transport, potentially allowing salinity-driven stratification to strengthen (an analogous scenario has been described for the glacial Antarctic [de Boer et al., 2008; Toggweiler et al., 2006]). However, countering these effects, a decrease in Ekman transport might have reduced the import of low-salinity, coastal water into the region. More importantly, integrated westerly wind strength over the North Atlantic may have intensified [Brauer et al., 2008], which would have added turbulence to the upper water column and thus deepened the mixed layer (Figure 4).

[36] The ice age deepening of the summer mixed layer inferred from the $\delta^{15} \mathrm{~N}$ and $\delta^{18} \mathrm{O}$ data may be related to the shift from NADW to GNAIW during ice ages and the associated southward shift in the locus of wintertime convection to the region of our core site [Oppo and Lehman, 1993]. Using planktonic foraminiferal $\delta^{18} \mathrm{O}$, Duplessy et al. [1991] and Labeyrie et al. [1992] argue for lower salinity during the LGM in the subpolar and polar North Atlantic except for an incursion of higher salinity into the region at $\sim 50-54^{\circ} \mathrm{N}$ and $\sim 30^{\circ} \mathrm{W}$, and they suggest that this region hosted GNAIW formation. These results are roughly supported by the dinoflagellate reconstruction of de Vernal et al. [2002], although there is a mismatch in the exact regions that the two studies identify as having greatest surface density. This mismatch aside, the reconstructed high surface density region in the eastern subpolar North Atlantic might be interpreted as resulting from the influx of Gulf Stream-derived warm and salty water, which was then quickly cooled under the subpolar atmosphere. Our site is at the outer margin of the salty (high-density) region reconstructed by Duplessy et al. [1991]; given the sites sampled by de Vernal et al. [2002], which are just to the southwest of V28-73, our results might be related to their reconstructed region of higher surface density. 
[37] The combined paleoproductivity and $\mathrm{N}$ isotope data contrast with data from the Antarctic and Subarctic North Pacific, where productivity was also reduced during the LGM but nutrient consumption was apparently more complete [Brunelle et al., 2007; Francois et al., 1997; Jaccard et al., 2005; Robinson and Sigman, 2008]. These changes have been argued to indicate reduced nutrient supply from below, providing the central evidence for reduced surface/ subsurface communication in the polar regions during ice ages, "polar stratification" [Sigman et al., 2010]. In this scenario for the Antarctic and North Pacific, the shift to higher nutrient consumption might have derived either from iron inputs from above and/or a shoaling of the spring/summer mixed layer. In this context, the apparently opposite response of subpolar North Atlantic nutrient consumption to LGM conditions begs for an explanation.

[38] In ocean model experiments, convection and deep water formation tend to show anticorrelation between the North Atlantic and Southern Ocean [Kuhlbrodt et al., 2007]. de Boer et al. [2008] argue that, for a global ocean state in which salinity is proportionally more important for deep convection, convection will be higher in North Atlantic but lower in the Antarctic and North Pacific; furthermore, they argue that the last ice age represents such a state. In ocean model experiments, this inverse behavior between the North Atlantic and Southern Ocean is typically part of a global compensation for regional changes in deep water formation. The compensation arises because, with a decrease in deep water formation in one region, the ocean interior gains buoyancy until convection in another polar region becomes favorable [Broecker, 1998; de Boer et al., 2007, 2008]. From this perspective, our findings of a deeper summer mixed layer in the ice age subpolar North Atlantic, to the degree that it is associated with winter mixed-layer deepening and GNAIW formation, might not simply be driven by local forcing but might rather be a part of a global ocean teleconnection that leads to inverse behavior in the North Atlantic and Antarctic, that is, the "bipolar seesaw" [Broecker, 1998].

\subsection{Heinrich Events}

[39] In the Heinrich layers, $\mathrm{FB}-\delta^{15} \mathrm{~N}$ is similar to that of the Holocene and thus suggests comparably complete nitrate consumption as observed today. Data on biogenic material and assemblages of planktonic and benthic foraminifera suggest that North Atlantic productivity was notably reduced, even relative to LGM productivity, which was in turn apparently lower than Holocene productivity (Figure 1) [Bond et al., 1992; Broecker et al., 1992; Nave et al., 2007; Thomas et al., 1995]. Combining this constraint with the $\mathrm{FB}-\delta^{15} \mathrm{~N}$ data suggests that increased stratification in the high-latitude North Atlantic during Heinrich events sharply reduced the flux of deep nutrients to the euphotic zone. This enhanced perennial stratification, with a shallower winter mixed layer, would also have yielded a shallower summer mixed layer (Figure 4). Given the evidence for reduced productivity, these periods cannot be described as conducive to phytoplankton growth; nevertheless, the environmental conditions apparently allowed phytoplankton to completely consume the weak nutrient supply.

[40] It would seem straightforward to argue for stronger surface layer freshening during Heinrich events as the cause for the increased upper ocean stratification that the paleoproductivity and $\mathrm{FB}-\delta^{15} \mathrm{~N}$ data together suggest. Indeed, the existence of $\mathrm{Nps} \delta^{18} \mathrm{O}$ minima during Heinrich events suggests the melting of iceberg derived freshwater [Bond et al., 1993; Bond et al., 1992]. However, at V2873 , we observe no such $\delta^{18} \mathrm{O}$ minima in either $\mathrm{Nps}$ or $\mathrm{Gb}$ but rather a slight rise in $\delta^{18} \mathrm{O}$ (Figure $3 \mathrm{~b}$ ), and this is consistent with much more exhaustive studies of $\mathrm{Nps} \delta^{18} \mathrm{O}$ in the region [Cortijo et al., 1997], which suggest that the Heinrich $\delta^{18} \mathrm{O}$ decrease is largely a feature of sediment cores further south, which are centered over the ice age IRD belt [Ruddiman, 1977] (Figure 2). Sea ice melt provides a possible mechanism for freshening the upper ocean without lowering $\delta^{18} \mathrm{O}$ (in fact, it can cause complex signals [Hillaire-Marcel and de Vernal, 2008]), while cooling could also work against the effect of water $\delta^{18} \mathrm{O}$ decline in determining the $\delta^{18} \mathrm{O}$ of foraminifera. Thus, the $\delta^{18} \mathrm{O}$ data do not seem to rule out freshening-driven water column stratification. Nevertheless, they do not provide any support for this interpretation. Adding further nuance to these considerations, Peck et al. [2006] observe declines in $\delta^{18} \mathrm{O}$ of Gb but not Nps in IRD layers in their site west of Ireland (Figure 2, core MD01-2461), which they interpret as freshening-driven upper ocean stratification, but their IRD layers typically are not the same as the Heinrich layers.

[41] For a site at the southern margin of the glacial IRD belt (Figure 2, CHN82-20, $43.3^{\circ} \mathrm{N}, 29.5^{\circ} \mathrm{W}$ ), Rashid and Boyle [2007] find that the $\delta^{18} \mathrm{O}$ of different foraminifera species converge during at least some Heinrich events, which they interpret as a sign of mixed-layer deepening. There might be mechanisms for reducing the nutrient supply to the subpolar North Atlantic without shoaling the mixed layer, so as to allow for consistency between the interpretation of Rashid and Boyle [2007] with our N isotope observations. However, there are also different viewpoints as to how to interpret the observed interspecies foraminiferal $\delta^{18} \mathrm{O}$ differences [Rashid and Boyle, 2008]. Hillaire-Marcel and de Vernal [2008] tentatively link the $\delta^{18} \mathrm{O}$ convergence of species to the subduction of low- $\delta^{18} \mathrm{O}$ brines from sea ice formation. Arguably the most likely explanation is that CHN82-20 is almost $15^{\circ}$ south of V28-73, such that the findings of Rashid and Boyle [2007] do not apply to our region.

[42] Here, we suggest an interpretation of the slight $\delta^{18} \mathrm{O}$ rises in both $\mathrm{Gb}$ and Nps during Heinrich events that appears to fit with the $\mathrm{N}$ isotope data. We have proposed above that the more similar $\delta^{18} \mathrm{O}$ of $\mathrm{Gb}$ and $\mathrm{Nps}$ during the ice age was caused by a deep base to the summer mixed layer (Figure $4 d$, blue line), such that it sat below the common depths of both species. For both species to remain similar in $\delta^{18} \mathrm{O}$ during the Heinrich events, we would then need to argue that they remained in the same water, either below or above the mixed layer. As a $\delta^{18} \mathrm{O}$ decline would have been expected with freshening of the mixed layer during Heinrich events, the tendency for slight $\delta^{18} \mathrm{O}$ rises suggests that the mixed layer may have shoaled above the common depths of both species (Figure 4d). Given that the $\delta^{18} \mathrm{O}$ data suggest that the two species are separated by the summer mixed-layer base in the Holocene, the implication is that the Heinrich event mixed layer was even shallower than that of the Holocene. In this scenario, the mixed layer was shallowest during the Heinrich events and deepest during the background LGM, with the Holocene having an intermediate summer mixedlayer depth (Figure 4). Of course, we recognize the 
speculative nature of this very literal interpretation of $\mathrm{Gb}$ and $\mathrm{Nps} \delta^{18} \mathrm{O}$ changes, and our interpretation of the $\mathrm{N}$ isotope data does not rely on it.

[43] The inferred H1 IRD layer is possibly different from the other Heinrich events in its relatively late onset of the $\mathrm{FB}-\delta^{15} \mathrm{~N}$ increase (Figure 3 ). As noted above, the IRD layer itself seems to undergo some depth changes in mineralogy. Further work will be needed to resolve whether this difference from the other IRD layers is robust.

[44] Taking a broader view, the contrasting behavior of this subpolar North Atlantic site and the Southern Ocean, raised previously in the context of the LGM background conditions, is also apparent in association with the Heinrich events. Antarctic opal flux data are taken to indicate higher nutrient supply during Heinrich events, presumably due to increased upwelling and/or vertical mixing [Anderson et al., 2009]. In contrast, the $\mathrm{FB}-\delta^{15} \mathrm{~N}$ and biogenic flux data for the subpolar North Atlantic together indicate reduced nutrient supply in this region, apparently associated with the development of strong upper water column stratification (Figure 4). During Heinrich events, the North Atlantic changes were likely driven by the external factor of accelerated ice discharge. The Antarctic changes, in contrast, are thought to represent a response to the North Atlantic changes, be it by an atmospheric connection [Toggweiler and Lea, 2010] or a feedback through the ocean interior [Broecker, 1998; Schmittner and Galbraith, 2008; Sigman et al., 2007]. This inverse behavior between regions fits with the expectations of North Atlantic/Antarctic compensation in maintaining deep ocean ventilation.

\subsection{Conclusions}

[45] Based on the foraminifera bound- $\delta^{15} \mathrm{~N}$ in planktonic foraminifera Neogloboquadrina pachyderma (sinistral) from the eastern subpolar North Atlantic, we infer that summertime nutrient consumption was less complete during the last ice age (Figure 4b). Coupling this with the evidence for reduced productivity in the ice age subpolar North Atlantic, we infer that light conditions were less favorable due to a deeper summer mixed layer in this eastern region of the subpolar North Atlantic, consistent with other findings from the region [Peck et al., 2006]. Across most of the polar/subpolar ocean, deep summer mixed layers reflect weak year-round density stratification. Thus, our results imply that the ice age eastern subarctic North Atlantic was less well stratified, and this may be related to the suggestion that this region was a locus of GNAIW formation [Duplessy et al., 1991; Labeyrie et al., 1992; Oppo and Lehman, 1993; Peck et al., 2007]. In contrast, the FB- $\delta^{15} \mathrm{~N}$ peaks in the Heinrich layers call for less nitrate supply and thus stronger upper water column stratification during these events, due to the previously reconstructed freshwater inputs during Heinrich events (Figure 4c). This is consistent with observations of sharply reduced GNAIW formation during Heinrich events [Maslin et al., 1995; Zahn et al., 1997; McManus et al., 2004; Willamowski and Zahn, 2000]. However, given the suggestions from foraminiferal $\delta^{18} \mathrm{O}$ and dinoflagellate cysts for extreme spatial variability in surface ocean salinity and density across the subpolar North Atlantic during the last ice age [de Vernal et al., 2002; Duplessy et al., 1991] and in Heinrich events [Cortijo et al., 1997], these changes in upper ocean conditions and their connections to North
Atlantic overturning must be investigated in other sites across the region.

[46] Acknowledgments. We thank M.A. Weigand, S. Oleynik, N Crompton, S. Breitenbach, and K. Ellis for technical assistance and advice. We also thank S. Hemming for giving M.M.T. access to her lab facilities and S. Myneni for his support with the FTIR measurements. Funding was provided by SNF foundation grant (200021-131886/1), US NSF grant OCE-1060947, and the NOAA Ernest F. Hollings Scholarship Program. This research used samples provided by the LDEO core repository. Two anonymous reviewers provided feedback that improved the manuscript.

\section{References}

Altabet, M. (2006), Isotopic tracers of the marine nitrogen cycle: Present and past marine organic matter: Biomarkers, Isotopes and DNA, edited by J. Volkman, pp. 251-293, Springer, Berlin / Heidelberg. doi:10.1007/698.

Altabet, M. A., and R. Francois (1994), Sedimentary nitrogen isotopic ratio as a recorder for surface ocean nitrate utilization, Global Biogeochem. Cycles, 8(1), 103-116.

Altabet, M. A., and R. Francois (2001), Nitrogen isotope biogeochemistry of the Antarctic Polar Frontal Zone at 170 degrees W, Deep Sea Res. Part II: Topical Studies Oceanogr., 48, 4247-4273.

Altabet, M. A., W. G. Deuser, S. Honjo, and C. Stienen (1991), Seasonal and depth-related changes in the source of sinking particles in the North Atlantic, Nature, 354(6349), 136-139.

Anderson, R. F., S. Ali, L. I. Bradtmiller, S. H. H. Nielsen, M. Q. Fleisher, B. E. Anderson, and L. H. Burckle (2009), Wind-driven upwelling in the Southern Ocean and the deglacial rise in atmospheric $\mathrm{CO}_{2}$, Science, 323 (5920), 1443-1448. doi:10.1126/science.1167441

Bond, G., W. Broecker, S. Johnsen, J. McManus, L. Labeyrie, J. Jouzel, and G. Bonani (1993), Correlations between climate records from North Atlantic sediments and Greenland ice, Nature, 365(6442), 143-147.

Bond, G., et al. (1992), Evidence for massive discharges of icebergs into the North-Atlantic Ocean during the last glacial period, Nature, 360(6401), 245-249.

Bond, G. C., and R. Lotti (1995), Iceberg discharges into the North Atlantic on millennial time scales during the last glaciation, Science, 267(5200), $1005-1010$.

Brauer, A., G. H. Haug, P. Dulski, D. M. Sigman, and J. F. W. Negendank (2008), An abrupt wind shift in western Europe at the onset of the Younger Dryas cold period, Nature Geosci., 1(8), 520-523. doi:10.1038/ngeo263.

Breitenbach, S. F. M., and S. M. Bernasconi (2011), Carbon and oxygen isotope analysis of small carbonate samples (20 to $100 \mathrm{ug}$ ) with a GasBench II preparation device, Rapid Commun. Mass Spectrom., 25(13), 1910-1914. doi:10.1002/rcm.5052.

Broecker, W., G. Bond, M. Klas, E. Clark, and J. McManus (1992), Origin of the northern Atlantic's Heinrich events, Clim. Dyn., 6(3-4), 265-273.

Broecker, W. S. (1998), Paleocean circulation during the last deglaciation: A bipolar seesaw?, Paleoceanogr., 13(2), 119-121.

Brunelle, B. G., D. M. Sigman, M. S. Cook, L. D. Keigwin, G. H. Haug, B. Plessen, G. Schettler, and S. L. Jaccard (2007), Evidence from diatombound nitrogen isotopes for subarctic Pacific stratification during the last ice age and a link to North Pacific denitrification changes, Paleoceanogr., 22(1), PA1215, doi:10.1029/2005PA001205

Cortijo, E., L. Labeyrie, L. Vidal, M. Vautravers, M. Chapman, J.-C Duplessy, M. Elliot, M. Arnold, J.-L. Turon, and G. R. Auffret (1997), Changes in sea surface hydrology associated with Heinrich event 4 in the North Atlantic Ocean between $40^{\circ}$ and $60^{\circ} \mathrm{N}$, Earth Planet. Sci. Lett., $146,29-45$

de Boer, A. M., J. R. Toggweiler, and D. M. Sigman (2008), Atlantic dominance of the meridional overturning circulation, J. Phys. Oceanogr., 38 (2), 435-450. doi:10.1175/2007JPO3731.1.

de Boer, A. M., D. M. Sigman, J. R. Toggweiler, and J. L. Russell (2007), Effect of global ocean temperature change on deep ocean ventilation, Paleoceanogr., 22(2), PA2210.

de Vernal, A., and C. Hillaire-Marcel (2000), Sea-ice cover, sea-surface salinity and halo-/thermocline structure of the northwest North Atlantic: modern versus full glacial conditions, Q. Sci. Rev. (19), 65-85.

de Vernal, A., C. Hillaire-Marcel, W. R. Peltier, and A. J. Weaver (2002), Structure of the upper water column in the northwest North Atlantic: Modern versus Last Glacial Maximum conditions, Paleoceanogr., 17 (4), 1050

DiFiore, P. J., D. M. Sigman, K. L. Karsh, T. W. Trull, R. B. Dunbar, and R. S. Robinson (2010), Poleward decrease in the isotope effect of nitrate assimilation across the Southern Ocean, Geophys. Res. Lett., 37(17), L17601, doi:10.1029/2010GL044090. 
Duplessy, J. C., L. Labeyrie, A. Juilletleclerc, F. Maitre, J. Duprat, and M. Sarnthein (1991), Surface salinity reconstruction of the North Atlantic Ocean during the Last Glacial Maximum, Oceanol. Acta, 14(4), 311-324.

Eguchi, N. O., H. Ujiie, H. Kawahata, and A. Taira (2003), Seasonal variations in planktonic foraminifera at three sediment traps in the subarctic, transition and subtropical zones of the central North Pacific Ocean, Mar Micropaleontol., 48, 149-163. doi:10.1016/S0377-8398(03)00020-3.

Fraile, I., M. Schulz, S. Mulitza, U. Merkel, M. Prange, and A. Paul (2009), Modeling the seasonal distribution of planktonic foraminifera during the Last Glacial Maximum, Paleoceanogr., 24(2), PA2216, doi:10.1029/ 2008PA001686.

Francois, R., and M. P. Bacon (1994), Heinrich events in the North Atlantic: Radiochemical evidence, Deep Sea Res. Part I: Oceanogr. Res. Papers, $41(2), 315-334$

Francois, R., M. A. Altabet, E.-F. Yu, D. M. Sigman, M. P. Bacon, M. Frank, G. Bohrmann, G. Bareille, and L. D. Labeyrie (1997), Contribution of Southern Ocean surface-water stratification to low atmospheric $\mathrm{CO}_{2}$ concentrations during the last glacial period, Nature, 389(6654), 929-935.

Fuhrer, K., E. W. Wolff, and S. J. Johnsen (1999), Timescales for dust variability in the Greenland Ice Core Project (GRIP) ice core in the last 100,000 years, J. Geophys. Res., 104(D24), 31043-31052.

Garcia, H. E., R. A. Locarnini, T. P. Boyer, J. I. Antonov, M. M. Zweng, O. K. Baranova, and D. R. Johnson (2010), World Ocean Atlas, 2009, Government Printing Office, Washington D.C.

Grousset, F. E., L. Labeyrie, J. A. Sinko, M. Cremer, G. Bond, J. Duprat, E. Cortijo, and S. Huon (1993), Patterns of ice-rafted detritus in the glacial North Atlantic $\left(40-55^{\circ} \mathrm{N}\right)$, Paleoceanogr., $8(2), 175-192$.

Hemming, S. R. (2004), Heinrich events: Massive late Pleistocene detritus layers of the North Atlantic and their global climate imprint, Rev. Geophys., 42(1), doi:10.1029/2003RG000128.

Hillaire-Marcel, C., and G. Bilodeau (2000), Instabilities in the Labrador Sea water mass structure during the last climatic cycle, Can. J. Earth Sci., 37(5), 795-809.

Hillaire-Marcel, C., and A. de Vernal (2008), Comment on "mixed-layer deepening during Heinrich events: A multi-planktonic foraminiferal $\delta^{18} \mathrm{O}$ approach", Science, 320(5880), 143-150. doi:10.1126/science.1153316.

Hodell, D. A., and J. H. Curtis (2008), Oxygen and carbon isotopes of detrital carbonate in North Atlantic Heinrich Events, Mar. Geol., 256, 30-35. doi:10.1016/j.margeo.2008.09.010.

Huon, S., F. E. Grousset, D. Burdloff, G. Bardoux, and A. Mariotti (2002), Sources of fine-sized organic matter in North Atlantic Heinrich Layers: $\delta^{13} \mathrm{C}$ and $\delta^{15} \mathrm{~N}$ tracers, Geochim. Cosmochim. Acta, 66(2), 223-239.

Jaccard, S. L., G. H. Haug, D. M. Sigman, T. F. Pedersen, H. R. Thierstein, and U. Röhl (2005), Glacial/interglacial changes in subarctic North Pacific stratification, Science, 308(5724), 1003-1006. doi:10.1126/science.1108696.

Ji, J., Y. Ge, W. Balsam, J. E. Damuth, and J. Chen (2009), Rapid identification of dolomite using a Fourier transform infrared spectrophotometer (FTIR): A fast method for identifying Heinrich events in IODP Site U1308, Marine Geol., 258, 60-68. doi:10.1016/j.margeo.2008.11.007.

Jonkers, L., G.-J. A. Brummer, F. J. C. Peters, H. M. van Aken, M. Hendrik, M. F. De Jong (2010), Seasonal stratification, shell flux, and oxygen isotope dynamics of left-coiling $N$. pachyderma and T. quinqueloba in the western subpolar North Atlantic, Paleoceanogr., 25, PA3209, doi:10.1029/ 2009PA001849.

Kuhlbrodt, T., A. Griesel, M. Montoya, A. Levermann, M. Hofmann, and S. Rahmstorf (2007), On the driving processes of the Atlantic meridional overturning circulation, Rev. Geophys., 45(2), RG2001, doi:10.1029/ 2004RG000166.

Labeyrie, L. D., J.-C. Duplessy, J. Duprat, A. Juillet-Leclerc, J. Moyes, E. Michel, N. Kallel, and N. J. Shackleton (1992), Changes in the vertical structure of the North Atlantic Ocean between glacial and modern times, Q. Sci. Rev., 11(4), 401-413.

Lourey, M. J., T. W. Trull, and D. M. Sigman (2003), Sensitivity of $\delta^{15} \mathrm{~N}$ of nitrate, surface suspended and deep sinking particulate nitrogen to seasonal nitrate depletion in the Southern Ocean, Global Biogeochem. Cycles, 17(3), 1081. doi:10.1029/2002GB001973.

Manighetti, B., and I. N. McCave (1995), Depositional fluxes, palaeoproductivity, and ice rafting in the NE Atlantic over the past $30 \mathrm{ka}$, Paleoceanogr., 10(3), 579-592.

Marinov, I., A. Gnanadesikan, J. L. Sarmiento, J. R. Toggweiler, M. Follows, and B. K. Mignone (2008), Impact of oceanic circulation on biological carbon storage in the ocean and atmospheric pCO2, Global Biogeochem. Cycles, 22(3), GB3007, doi:10.1029/2007GB002958.

Maslin, M. A., N. J. Shackleton, and U. Pflaumann (1995), Surface water temperature, salinity, and density changes in the Northeast Atlantic during the last 45,000 years: Heinrich events, deep water formation, and climatic rebounds, Paleoceanogr., 10(3), 527-544.

McIntyre, A., N. Kipp, A. W. H. Be, T. Crowley, J. V. Gardener, W. L. Prell, and W. F. Ruddiman (1976), Glacial North Atlantic 18,000 years ago: a CLIMAP reconstruction, 43-76 pp., Geol. Soc. Am. Mem.
McManus, J. F., R. Francois, J. M. Gherardi, L. D. Keigwin, and S. BrownLeger (2004), Collapse and rapid resumption of Atlantic meridional circulation linked to deglacial climate changes, Nature, 428(6985), 834-837. doi:10.1038/nature02494.

Meckler, A. N., H. Ren, D.M. Sigman, N. Gruber, B. Plessen, C.J. Schubert, G. Haug (2011), Deglacial nitrogen isotope changes in the Gulf of Mexico: Evidence from bulk sedimentary and foraminifera-bound nitrogen in Orca Basin sediments, Paleoceanogr., 26, PA4216, doi:10.1029/ 2011PA002156.

Monterey, G. I., and S. Levitus (1997), Climatological cycle of mixed layer depth in the world ocean, 5pp. U.S. Gov. Printing Office, NOAA, NESDIS, Boulder, Colorado, USA

Nave, S., L. Labeyrie, J. Gherardi, N. Caillon, E. Cortijo, C. Kissel, and F. Abrantes (2007), Primary productivity response to Heinrich events in the North Atlantic ocean and Norwegian sea, Paleoceanogr., 22(3), PA3216, doi:10.1029/2006PA001335.

Oppo, D. W., and S. J. Lehman (1993), Mid-depth circulation of the subpolar North Atlantic during the Last Glacial Maximum, Science, 259(5098), $1148-1152$.

Peck, V. L., I. R. Hall, R. Zahn, and J. D. Scourse (2007), Progressive reduction in NE Atlantic intermediate water ventilation prior to Heinrich events: Response to NW European ice sheet instabilities?, Geochem. Geophys. Geosyst., 8, Q01n10, doi:10.1029/2006gc001321.

Peck, V. L., I. R. Hall, R. Zahn, H. Elderfield, F. Grousset, S. R. Hemming, and J. D. Scourse (2006), High resolution evidence for linkages between NW European ice sheet instability and Atlantic meridional overturning circulation, Earth Planet. Sci. Lett., 243, 476-488. doi:10.1016/j. epsl.2005.12.023.

Rashid, H., and E. A. Boyle (2007), Mixed-layer deepening during Heinrich events: A multi-planktonic foraminiferal $\delta^{18} \mathrm{O}$ approach, Science, 318 (5849), 439-441. doi:10.1126/science.1146138.

Rashid, H., and E. A. Boyle (2008), Response to comment on "Mixed-layer deepening during Heinrich events: a multi-planktonic foraminiferal $\delta^{18} \mathrm{O}$ approach", Science, 320(5880), 1161-1161. doi:10.1126/ science. 1153646

Ren, H., D. M. Sigman, M. E. Chen, and S. Kao (2012a), Elevated foraminifera-bound nitrogen isotopic composition during the last ice age in the South China Sea and its global and regional implications, Global Biogeochem. Cycles, 26(1), GB1031, doi:10.1029/ $2010 \mathrm{~GB} 004020$.

Ren, H., D. M. Sigman, A. N. Meckler, B. Plessen, R. S. Robinson, Y. Rosenthal, and G. H. Haug (2009), Foraminiferal isotope evidence of reduced nitrogen fixation in the ice age Atlantic Ocean, Science, 323(5911), 244-248

Ren, H., D.M. Sigman, R.C. Thunell, M.G. Prokopenko (2012b), Nitrogen isotopic composition of planktonic foraminifera from the modern ocean and recent sediments, Limnol. Oceanogr., 57, 1011-1024.

Robinson, R. S., and D. M. Sigman (2008), Nitrogen isotopic evidence for a poleward decrease in surface nitrate within the ice age Antarctic, $Q$. Sci. Rev., 27, 1076-1090. doi:10.1016/j.quascirev.2008.02.005.

Ruddiman, W. F. (1977), Late Quaternary deposition of ice-rafted sand in the subpolar North Atlantic (lat $40^{\circ}$ to $65^{\circ} \mathrm{N}$ ), Geol. Soc. Am. Bull., 88 (12), 1813-1827.

Ruddiman, W. F., and A. McIntyre (1977), Late Quaternary surface ocean kinematics and climatic change in the high-latitude North Atlantic, $J$. Geophys. Res., 82(27), 3877-3887.

Sarnthein, M., U. Pflaumann, and M. Weinelt (2003), Past extent of sea ice in the northern North Atlantic inferred from foraminiferal paleotemperature estimates, Paleoceanogr., 18(2), 1047. doi:10.1029/2002PA000771.

Sautter, L. R., and R. C. Thunell (1989), Seasonal succession of planktonicforaminifera. Results from a 4-year time series sediment trap experiment in the northeast Pacific, J. Foraminifer. Res., 19(4), 253-267.

Schmittner, A., and E. D. Galbraith (2008), Glacial greenhouse-gas fluctuations controlled by ocean circulation changes, Nature, 456(7220), 373-376. doi:10.1038/nature07531.

Schubert, C. J., and S. E. Calvert (2001), Nitrogen and carbon isotopic composition of marine and terrestrial organic matter in Arctic Ocean sediments: implications for nutrient utilization and organic matter composition, Deep Sea Res. Part I: Oceanogr. Res. Papers, 48(3), 789-810.

Siegel, D. A., S. C. Doney, and J. A. Yoder (2002), The North Atlantic spring phytoplankton bloom and Sverdrup's critical depth hypothesis, Science, 296(5568), 730-733

Sigman, D. M., A. M. de Boer, and G. H. Haug (2007), Antarctic stratification, atmospheric water vapor, and Heinrich events: A hypothesis for Late Pleistocene deglaciations, in Ocean Circulation: Mechanisms and Impacts; Past and Future Changes of Meridional Overturning, pp. 335-349, AGU, Washington, DC. doi:10.1029/173GM21.

Sigman, D. M., M. P. Hain, and G. H. Haug (2010), The polar ocean and glacial cycles in atmospheric $\mathrm{CO}_{2}$ concentration, Nature, 466(7302), 47-55. doi:10.1038/nature09149. 


\section{STRAUB ET AL.: NORTH ATLANTIC NUTRIENT CONDITIONS}

Sigman, D. M., M. A. Altabet, D. C. McCorkle, R. Francois, and G. Fischer (1999), The d15N of nitrate in the southern ocean: Consumption of nitrate in surface waters, Global Biogeochem. Cycles, 13(4), 1149-1166.

Sigman, D. M., M. A. Altabet, D. C. McCorkle, R. Francois, and G. Fischer (2000), The delta N-15 of nitrate in the Southern Ocean: Nitrogen cycling and circulation in the ocean interior, J. Geophys. Res.-Oceans, 105(C8), 19599-19614.

Sigman, D. M., P. J. DiFiore, M. P. Hain, C. Deutsch, Y. Wang, D. M. Karl, A. N. Knapp, M. F. Lehmann, and S. Pantoja (2009), The dual isotopes of deep nitrate as a constraint on the cycle and budget of oceanic fixed nitrogen, Deep Sea Res. Part I: Oceanogr. Res. Papers, 56(9), 1419-1439. doi:10.1016/j.dsr.2009.04.007.

Stephens, B. B., and R. F. Keeling (2000), The influence of Antarctic sea ice on glacial-interglacial $\mathrm{CO}_{2}$ variations, Nature, 404(6774), 171-174.

Thomas, E., L. Booth, M. Maslin, and N. J. Shackleton (1995), Northeastern Atlantic benthic foraminifera during the last 45,000 years: Changes in productivity seen from the bottom up, Paleoceanogr., 10(3), 545-562.

Thunell, R. C., and L. A. Reynolds (1984), Sedimentation of planktonic foraminifera; seasonal changes in species flux in the Panama Basin, Micropaleontol., 30(3), 243-262.

Thunell, R. C., and S. Honjo (1987), Seasonal and interannual changes in planktonic foraminiferal production in the North Pacific, Nature, 328 (6128), 335-337.

Toggweiler, J. R., and D. W. Lea (2010), Temperature differences between the hemispheres and ice age climate variability, Paleoceanogr., 25 , doi:10.1029/2009PA001758.

Toggweiler, J. R., J. L. Russell, and S. R. Carson (2006), Midlatitude westerlies, atmospheric $\mathrm{CO} 2$, and climate change during the ice ages, Paleoceanogr., 21(2), PA2005, doi:10.1029/2005PA001154.
Toggweiler, J. R., A. Gnanadesikan, S. Carson, R. Murnane, and J. L. Sarmiento (2003), Representation of the carbon cycle in box models and GCMs: 1. Solubility pump, Global Biogeochem. Cycles, 17(1), 1026, doi:10.1029/2001GB001401

Uhle, M. E., S. A. Macko, H. J. Spero, M. H. Engel, and D. W. Lea (1997), Sources of carbon and nitrogen in modern planktonic foraminifera: The role of algal symbionts as determined by bulk and compound specific stable isotopic analyses, Org. Geochem., 27, 103-113.

van Weering, T. C. E., and S. de Rijk (1991), Sedimentation and climateinduced sediments on Feni Ridge, Northeast Atlantic Ocean, Mar. Geol., 101, 49-69.

Villanueva, J., J. O. Grimalt, E. Cortijo, L. Vidal, and L. Labeyriez (1997), A biomarker approach to the organic matter deposited in the North Atlantic during the last climatic cycle, Geochim. Cosmochim. Acta, 61(21), 4633-4646.

Waelbroeck, C., et. al. (2009), Constraints on the magnitude and patterns of ocean cooling at the Last Glacial Maximum, Nature Geosci., 2(2), 127-132. doi:10.1038/ngeo411.

Willamowski, C., and R. Zahn (2000), Upper ocean circulation in the Glacial North Atlantic from benthic foraminiferal isotope and trace element fingerprinting, Paleoceanogr., 15(5), 515-527.

Zahn, R., J. Schoenfeld, H.-R. Kudrass, M.-H. Park, H. Erlenkeuser, and P. Grootes (1997), Thermohaline instability in the North Atlantic during meltwater events: stable isotope and ice-rafted detritus records from core SO75-26KL, Portuguese margin, Paleoceanogr., 12(5), 696-710.

Zaric, S., B. Donner, G. Fischer, S. Mulitza, and G. Wefer (2005), Sensitivity of planktic foraminifera to sea surface temperature and export production as derived from sediment trap data, Mar. Micropaleontol., 55 75-105. doi:10.1016/j.marmicro.2005.01.002. 